\title{
Studi Eksperimen dan Analisa Laju Keausan Material Alternatif pada Sepatu Rem Lokomotif
}

\author{
Eskaridho Gultom dan Yusuf Kaelani \\ Jurusan Teknik Mesin, Fakultas Teknologi Industri, Institut Teknologi Sepuluh Nopember Surabaya (ITS) \\ Jl. Arief Rahman Hakim, Surabaya 60111 \\ e-mail:y_kaelani@me.its.ac.id
}

\begin{abstract}
Abstrak-Sepatu rem yang digunakan pada sistem pengereman lokomotif pada umumnya, sering mengalami keausan dini yang diakibatkan oleh beban lokomotif berikut gerbong penumpang dan jarak tempuh pengereman yang cukup jauh. Hal ini terjadi dikarenakan adanya kontak antara brake shoes dan material besi sebagai roda lokomotif. Oleh karena itu perlu dilakukan penelitian untuk mengetahui laju keausan material alternatif sepatu rem baru dengan menggunakan SS316 sebagai kontak pergesekan.Spesimen uji ditimbang dengan timbangan digital sebelum dilakukan pengujian untuk mengetahui berat awal dan mengetahui harga kekerasan material altenatif baru sepatu rem resin serbuk baja. Pengujian dilakukan dengan menggunakan kecepatan konstan maksimum yaitu 59,2 rpm dengan tiga variasi beban mendekati maksimum hingga maksimum sebesar $90 \mathrm{~N}, 120 \mathrm{~N}$ dan $150 \mathrm{~N}$ dan beban konstan maksimum sebesar $150 \mathrm{~N}$ dengan tiga variasi kecepatan mendekati maksimum hingga maksimum sebesar 52,4 rpm, $56 \mathrm{rpm}$ dan 59,2 rpm. Hasil yang diperoleh dari penelitian ini adalah analisa laju keausan antara material alternatif resin serbuk baja dengan dua dimensi spesimen pengujian yang digesekkan dengan material stainless steel 316 sebagai disk. Pada kedua metode pengujian memperoleh nilai rata-rata laju keausan $4114,9658 \mathrm{~mm}^{3} / \mathrm{m}^{3}$ untuk variasi kecepatan dan $5593,7517 \mathrm{~mm}^{3} / \mathrm{m}^{3}$ untuk variasi beban dari perolehan wear volume sebesar $1.554063 \mathrm{~mm}^{3}$ dan $1.685238 \mathrm{~mm}^{3}$. Pada tingkat laju keausan tertinggi, diperoleh umur masing-masing spesimen berdasarkan alat uji tribometer pin on disk untuk variasi kecepatan selama 1,12 tahun dan 1,48 tahun untuk pengujian dengan variasi beban.
\end{abstract}

Kata Kunci - kekerasan, laju keausan, material alternatif resin serbuk baja, tribometer pin on disk, umur, variasi beban, variasi kecepatan.

\section{PENDAHULUAN}

$\mathrm{S}$ ALAH satu bagian penting dari sistem kendaraan atau lokomotif adalah pengereman. Untuk bisa beroperasi dengan baik kendaraan yang meaju harus bisa dihentikan perjalanannya karena sudah sampai pada tujuan atau karena ada rintangan yang menghalangi laju kereta api tersebut. Prinsip pengereman adalah merubah energi kinetik. menjadi energi panas melalui kontak dua permukaan antara roda dan sepatu rem. Bila masinis kereta mengaktifkan katup rem, udara yang dimampatkan bergerak dari pipa rem, masuk katup kendali dan terus ke silinder rem. Tekanan udara dalam silinder rem menggerakkan tuas yang menekankan sepatu rem ke roda kereta. Melepaskan katup rem menyebabkan tekanan udara lepas dari silinder rem dan sepatu rem pun menjauhi roda. Katup kendali itu juga memicu rem secara otomatis apabila sebuah gerbong terlepas dari bagian kereta lainnya. Sebuah tabung tambahan menyimpan cadangan udara termampatkan yang akan digunakan dalam keadaan darurat.
Permasalahan yang sering dialami oleh dunia industri atau perkeretaapian adalah bagaimana cara meminimalisir kerugian keausan atau membuat material alternatif baru terjadi pada dua komponen mesin saling menekan dan saling bergesekan. Keausan jenis ini terjadi apabila suatu partikel keras (asperity) dari material tertentu meluncur pada permukaan material lain yang lebih lunak sehingga terjadi penetrasi atau pemotongan material yang lebih lunak. Tingkat keausan pada mekanisme ini ditentukan oleh derajat kebebasan (degree of freedom) partikel keras atau asperity tersebut[3]. Keausan paling besar terjadi pada benda benda lunak. Faktor - faktor yang yang mempengaruhi keausan adalah kecepatan, tekanan, kekasaran permukaan dan kekerasan material. Pada dasarnya salah satu faktor yang mempengaruhi keausan adalah kekerasan material komponen. Kekerasan material didapatkan dari terobosan material baru. Material alternatif yang akan dianalisa laju keausannya merupakan material paduan antara resin dan serbuk baja hasil penempaan.

Maka dari itu pada tugas akhir ini dilakukan penelitian untuk mengetahui seberapa besar pengaruh material alternatif baru sepatu rem terhadap laju keausan (wear rate) dengan memvariasikan dua bagian dari enam spesimen hasil potongan material alternatif pada permukaan yang berbeda dengan luasan bidang spesimen yang berbeda dengan luasan sebesar $(15 \mathrm{~mm} \times 13 \mathrm{~mm} \times 7 \mathrm{~mm})$ untuk eksperimen dengan variasi kecepatan dan $(15 \mathrm{~mm} \times 14 \mathrm{~mm} \times 9 \mathrm{~mm})$ untuk eksperimen dengan variasi beban. Pada kedua bagian spesimen tersebut dilakukan pengujian dengan spesifikasi maksimum pada alat tribometer dan mencari life time dari material serta merekomendasikan material alternatif sabots yang memiliki laju keausan yang lebih baik daripada material yang digunakan pada umumnya disistem pengereman lokomotif. Skala perbandingan kondisi alat uji tipe pin on disk dengan kondisi real sebesar 1:65,87 untuk skala kecepatan dan 1:59,66 untuk skala pembebanan.

\section{A. Material Alternatif Sepatu Rem (Paduan Resin Dan Serbuk Baja)}

Material alternatif ini merupakan material paduan antara resin dengan serbuk baja yaitu dengan menggabungkan kedua unsur-unsur material dengan unsur tambahan pada komposisi tertentu. Proses pembuatan material alternatif baru ini yaitu dengan proses tempa panas pada cetakan khusus yang hanya diperuntukkan dalam studi eksperimen saja, dimana material alternatif yang dibuat sebagai sampel alternatif baru sepatu rem pada sistem pengereman roda lokomotif memiliki komposisi pada Tabel 1. 
Tabel 1 Komposisi Material Alternatif Sepatu Rem Resin Serbuk Baja

\begin{tabular}{cc}
\hline \hline Komponen & Konsentrasi Unit (\%) \\
\hline $\mathrm{Fe}$ & 43.2 \\
$\mathrm{Al}$ & 26 \\
$\mathrm{Zn}$ & 8.16 \\
$\mathrm{Ba}$ & 5.40 \\
$\mathrm{Cu}$ & 5.35 \\
$\mathrm{Si}$ & 4.7 \\
$\mathrm{Ni}$ & 2.820 \\
$\mathrm{Ca}$ & 1.20 \\
$\mathrm{~Pb}$ & 1.1 \\
$\mathrm{Eu}$ & 0.6 \\
$\mathrm{~T}$ & 0.43 \\
$\mathrm{P}$ & 0.41 \\
$\mathrm{Os}$ & 0.4 \\
\hline \hline
\end{tabular}

\section{B. Dasar-dasar Perhitungan}

Dari spesifikasi material diatas pengujian keausan pada penelitian ini juga memiliki parameter-parameter kecepatan, perubahan massa akibat gesekan, gaya penekanan, lintasan dan waktu [1]. Dasar-dasar perhitungan laju keausan pertama-tama dilakukan dengan mencari waktu pengujian terlebih dahulu yang bergantung pada lintasan atau track saat pengujian pada alat tribometer. Jarak lintasan dan variabel putaran pada alat tribometer adalah parameter penentu untuk menentukan waktu atau lama pengujian keausan pada material resin serbuk baja tersebut. Adapun rumus yang digunakan untuk menentukan waktu pengujian pada material alternatif ini adalah sebagai berikut:

$$
t=\frac{\mathrm{L}}{\pi \cdot d \cdot R p m}
$$

Keterangan :

$$
\begin{array}{ll}
\mathrm{t} & =\text { waktu pengujian (menit) } \\
\mathrm{L} & =\text { panjang track pin (meter) } \\
\mathrm{d} & =\text { diameter track pin (meter) }
\end{array}
$$

Pada perhitungan ini, ada parameter yang harus didapat terlebih dahulu yaitu kekerasan material alternatif sepatu rem resin serbuk baja. Nilai keausan pada material alternatif sepatu rem bisa diperoleh dengan mendapatkan perbandingan berat atau massa setelah dilakukan pengujian pada alat tribometer. Perubahan massa pin $\Delta \mathrm{m}$ didapatkan dengan menimbang pin menggunakan timbangan digital sebelum dilakukan pengujian dan setelah dilakukan pengujian[4]. Setelah $\Delta \mathrm{m}$ diketahui, berikutnya mulai menghitung perubahan volume $(\Delta \mathrm{V})$ pin yang terjadi dengan menggunakan rumus dibawah ini:

$$
\Delta \mathrm{V}=\frac{\Delta \mathrm{m}}{\rho}
$$

Maka wear rate $\mathrm{K}$ dapat dicari dengan rumus

$$
\begin{aligned}
\frac{\mathrm{V}}{\mathrm{L}} & =\mathrm{K} \frac{\mathrm{F}}{\mathrm{H}} \\
\mathrm{V} & =\left(\frac{\mathrm{K}}{\mathrm{H}}\right) \mathrm{F} \cdot \mathrm{L} \\
\mathrm{K} & =\frac{\mathrm{H} \cdot \Delta \mathrm{V}}{\mathrm{F} \cdot \mathrm{L}}
\end{aligned}
$$

Pada eksperimen ini setelah dicari nilai laju keausan (wear rate), maka akan didapatkan umur hidup dari material alternatif sepatu rem resin serbuk baja. Perhitungan umur hidup pada material alternatif sepatu rem resin serbuk baja menggunakan rumus sebagai berikut:

$$
\begin{aligned}
\mathrm{t} & =\frac{\mathrm{L}}{\mathrm{v}} \\
\mathrm{t} & =\text { umur hidup material (secons) } \\
\mathrm{L} & =\text { panjang lintasan }(\text { meter }) \\
\mathrm{v} & =\text { kecepatan rata }-\operatorname{rata}(\mathrm{m} / \mathrm{s})
\end{aligned}
$$

Dimana untuk mencari nilai $\mathrm{L}$ dapat diperoleh dengan menggunakan rumus:

$$
\mathrm{L}=\frac{\mathrm{VxH}}{\mathrm{kxW}}
$$

$$
\begin{aligned}
& \mathrm{L}=\text { Panjang Lintasan (meter) } \\
& \mathrm{V}=\text { Volume Batas Aus yang Diijinkan }\left(\mathrm{m}^{3}\right) \\
& \mathrm{H}=\text { Nilai Kekerasan Material } \\
& \mathrm{K}=\text { Nilai Laju Keausan }\left(\mathrm{mm}^{3} / \mathrm{m}^{3}\right) \\
& \mathrm{W}=\text { Berat Pembebanan }(\mathrm{N})
\end{aligned}
$$

\section{METODOLOGI}

Penelitian ini dilakukan melalui beberapa langkah kerja sebagai studi eksperimental. Awalnya melakukan persiapan spesimen, yaitu membuat pin cekam yang terbuat dari baja ST-37, mencari hardness pada masing-masing spesimen uji, spesimen, melakukan pemotongan pada spesimen, resin serbuk baja siap uji yang dicekam oleh pin cekam baja ST37 dan disk dari SS 316. Penelitian dilakukan dengan menggunakan alat uji tribometer tipe Pin on Disk. Pin diletakkan diatas disk yang diputar dengan menggunakan motor. Pada penelitian ini terdapat beberapa variabel yaitu variasi kecepatan dan beban sebesar $0,19201 \mathrm{~m} / \mathrm{s}$ (speed control 80), 0,20525 m/s (speed control 90), dan 0,21697 $\mathrm{m} / \mathrm{s}$ (speed control 100) dan Pembebanan sebesar $8 \mathrm{~kg}, 10$ $\mathrm{kg}$ dan $12 \mathrm{~kg}$. Pengujian yang dilakukan adalah dengan menetapkan kecepatan konstan maksimum untuk variasi beban dan pembebanan konstan maksimum untuk variasi kecepatan. Lintasan diasumsikan konstan sepanjang $1200 \mathrm{~m}$. waktu pengujian tergantung pada masing-masing variasi kecepatan. Keausan dilihat dari perubahan massa yang terjadi pada spesimen antara sebelum dan sesudah spesimen dilakukan pengujian dengan presisi penimbangan $10^{-4} \mathrm{~g}$ Marusic, dkk (2004) [2]. Setelah dilakukan pengujian permukaan pin akan di foto mikro untuk mengetahui mekanisme keausan yang terjadi. Alat tribometer yang digunakan dalam penelitian ini dapat dilihata pada Gambar 2 berikut ini.

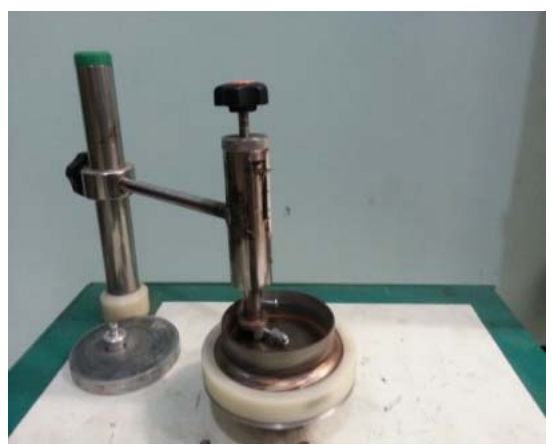

Gambar 2. Tribometer Tipe Pin on Disk 


\section{HASIL DAN PEMBAHASAN}

Pada bagian ini akan dibahas dan dianalisa hasil perolehan data kekerasan, eksperimen tentang laju keausan masing-masing prilaku pengujian dengan Stainless Steel SS 316 dan life time dari hasil perolehhan nilai wear rate pada spesimen uji. Pembahasan dimulai dengan penelitian laju keausan material resin serbuk baja. Berikut data hasil pengujian.

Tabel 1 Data Perhitungan Hasil Pengujian Spesimen I

\begin{tabular}{|c|c|c|c|c|c|c|c|c|c|c|c|c|c|c|}
\hline $\begin{array}{l}\text { Load } \\
(\mathrm{kg})\end{array}$ & $\begin{array}{l}\text { Speed } \\
\text { Control } \\
(\mathrm{pmm})\end{array}$ & $\begin{array}{l}\text { Sididing } \\
\text { Speed V } \\
(\mathrm{m} / \mathrm{s})\end{array}$ & $D(m)$ & $\begin{array}{l}\text { Time } \\
\text { (Menit) }\end{array}$ & $\begin{array}{c}V \\
\left(\mathrm{~mm}^{3}\right)\end{array}$ & $\begin{array}{l}M_{0} \\
\left(g g^{2}\right)\end{array}$ & $\begin{array}{l}M_{A} \\
(g r)\end{array}$ & Im & $\begin{array}{c}\mathrm{H} \\
\left(\mathrm{N} \mathrm{m}^{2}\right)^{2}\end{array}$ & $\begin{array}{c}\rho \\
\left(g \mathrm{~g} / \mathrm{mm}^{3}\right)\end{array}$ & $\begin{array}{l}\text { Sididing } \\
\text { Distance } \\
\text { L(m) }\end{array}$ & $F(N)$ & $\Delta V\left(\mathrm{~mm}^{3}\right)$ & $K\left(\mathrm{~mm}^{3} / \mathrm{m}^{3}\right)$ \\
\hline 12 & 52.4 & 0.19201 & 0.070 & 104.1891 & 1365 & 2,4124 & 2,4057 & 0.0067 & $3.85 E+08$ & 0.00177 & 1200 & 120 & 3.7911038 & \\
\hline 12 & 56 & 0.20525 & 0.070 & 97.4912 & 1365 & 2,5260 & 2,5247 & 0.0013 & $3.766+08$ & 0.00185 & 1200 & 120 & 0.702494 & \\
\hline 12 & 59.2 & 0.21697 & 0.070 & 92.2214 & 1365 & 2,4280 & 2.4277 & 0.0003 & $3.655+08$ & 0.00178 & 1200 & 120 & 0.168657 & 4.274999855+02 \\
\hline
\end{tabular}

Tabel 2 Data Perhitungan Hasil Pengujian Spesimen II

\begin{tabular}{|c|c|c|c|c|c|c|c|c|c|c|c|c|c|c|}
\hline & $\begin{array}{l}\text { Speed } \\
\text { Control } \\
(\mathrm{rpm})\end{array}$ & $\begin{array}{l}\text { Siliding } \\
\text { Speed V } \\
(\mathrm{m} / \mathrm{s})\end{array}$ & $D(m)$ & $\begin{array}{l}\text { Time } \\
\text { (Menit) }\end{array}$ & $\begin{array}{c}V \\
\left(\mathrm{~mm}^{3}\right)\end{array}$ & $\begin{array}{l}M_{0} \\
(g r)\end{array}$ & $\begin{array}{l}M_{A} \\
(g r)\end{array}$ & $\mathrm{dm}$ & $\begin{array}{c}\mathrm{H} \\
\left(\mathrm{N}^{2}{ }^{2}\right)\end{array}$ & $\begin{array}{c}\rho \\
\left(\mathrm{gt} / \mathrm{mm}^{3}\right)\end{array}$ & \begin{tabular}{|c} 
Sididing \\
Distance \\
L(m)
\end{tabular} & $\mathrm{F}(\mathrm{N})$ & & \\
\hline & & 0.21697 & 0.070 & & 1890 & 3.8760 & 3.8708 & & $3.65 E+08$ & & & & & \\
\hline & & 0.21697 & & 92.2214 & 1890 & 3.7144 & 3.7100 & 0.0044 & 4.00E+ +08 & |. 000121 & 1200 & & 2,238854 & \\
\hline & & 0.21697 & 0.070 & 92.2214 & 1890 & 4.0319 & 4.0313 & 0.0006 & $3.88 E+08$ & 0.00213 & 1200 & 120 & 0.281257 & 7.5783 \\
\hline
\end{tabular}

\section{A. Analisa Pengaruh Pembebanan terhadap Wear Rate} dengan dengan Variasi Tiga Variasi Kecepatan

Hasil dari pengujian laju keausan pada resin serbuk baja dengan Stainless Steel SS 316. Perbandingan Specific Wear Rate antara Speed Control 80 (kecepatan 0,19201 $\mathrm{m} / \mathrm{s})$,Speed Control $90(0,20525 \mathrm{~m} / \mathrm{s})$ dan speed control 100 (kecepatan 0,21697 m/s) pada pembebanan 12kg. Pengujian pertama untuk mengetahui nilai wear rate dilakukan pada spesimen resin serbuk baja dengan dimensi $15 \mathrm{~mm} \times 13 \mathrm{~mm} \times 7 \mathrm{~mm}$ dapat dilihat pada Gambar 3

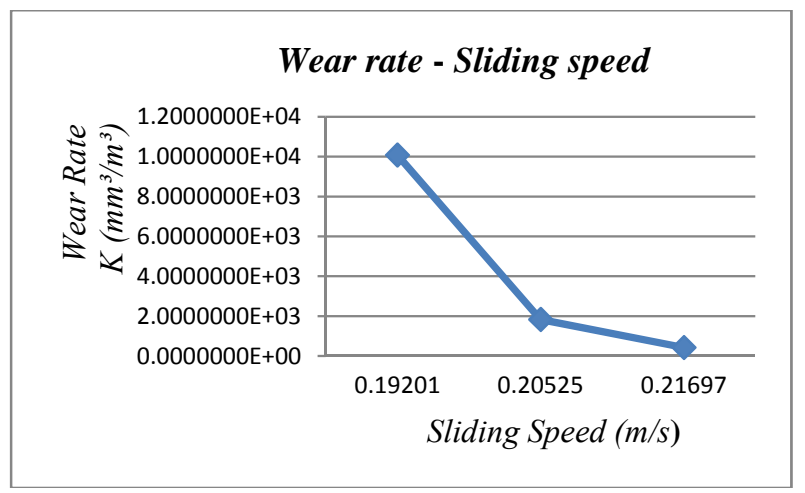

Gambar 3. Grafik Wear Rate terhadap Kecepatan dengan Pembebanan Konstan Maksimum $120 \mathrm{~N}$

Pada Gambar 3 dapat dilihat bahwa Nilai wear rate terlihat berbanding lurus dengan kecepatan, semakin besar kecepatan yang diberikan, semakin turun pula laju keausan material. Perubahan grafik wear rate terlihat tidak linear. Dimulai dari kecepatan 0,19201 m/s hingga kecepatan $0,21697 \mathrm{~m} / \mathrm{s}$ tren grafik selalu turun. Pada kecepatan $0,19201 \mathrm{~m} / \mathrm{s}$ nilai wear rate-nya adalah $1,00831079 \times 10^{4}$ $\mathrm{mm}^{3} / \mathrm{m}^{3}$, pada kecepatan $0,20525 \mathrm{~m} / \mathrm{s}$ nilai wear rate-nya berkurang kembali sebesar $1,83429005 \times 10^{3} \mathrm{~mm}^{3} / \mathrm{m}^{3}$, dan semakin rendah pada kecepatan $0,21697 \mathrm{~m} / \mathrm{s}$ yaitu $4,27499485 \times 10^{2} \mathrm{~mm}^{3} / \mathrm{m}^{3}$.
Secara teoritis, nilai wear rate akan semakin besar dengan semakin besarnya nilai kecepatan yang diberikan, namun tidak pada material alternatif ini kecenderungan saat kecepatan pertama menurun secara signifikan kecil oleh mekanisme abrasif yaitu partikel keras (asperity) dari material tertentu meluncur pada permukaan resin serbuk baja yang lebih lunak sehingga terjadi penetrasi atau pemotongan material yang lebih lunak dibandingkan dengan kecepatan kedua dan ketiga. Pada pengujian kedua dan ketiga material resin serbuk baja yang diuji dengan kecepatan yang lebih tinggi akan lebih cepat mengalami peningkatan temperatur yang semakin memperkeras permukaannya sehingga gerusan yang terjadi relatif lebih kecil dengan pengaruh unsur logam juga didalamnya, pengaruh dari masing-masing spesimen yang mempunyai harga kekerasan yang relatif berbeda, setiap permukaan spesimen pada permukaan komposisi material yang dominan terhadap material logam antar permukaan tergesek, deformasi plastis dan konsentrasi dari bubuk resin pada permukaan disk yang relatif keras juga mempengaruhi penurunan laju keausan. Pada kondisi operasinya, ketika nilai wear rate rendah maka akan berpengaruh pada umur hidup (lifetime) material tersebut yang relatif lebih lama.

\section{B. Analisa Pengaruh Pembebanan Terhadap Wear Volume Dengan Tiga Variasi Kecepatan}

Selain nilai wear rate, didaptkan nilai volume aus pada material dengan variasi kecepatan dimana terjadi penurunan volume aus semakin meningkatnya kecepatan. Peningkatan ini terjadi karena temepratur dan gesekan antar permukaan logam akibat kecepatan tinggi. Dapat dilihat pada gambar 4 dibawah ini.

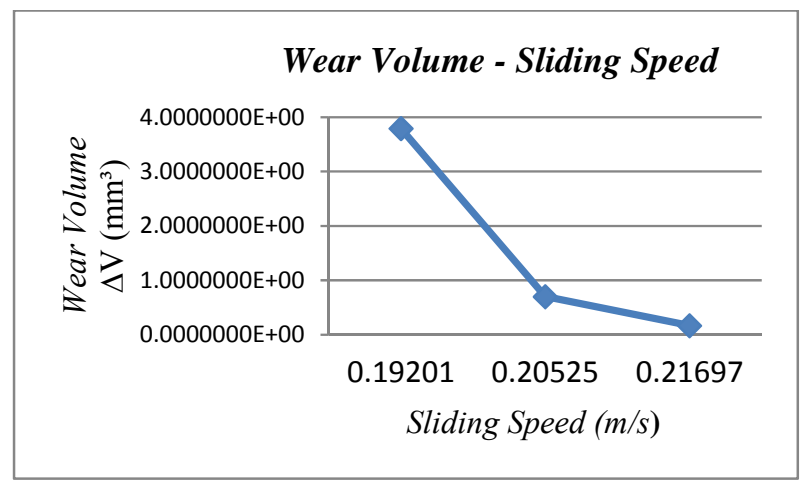

Gambar 4 Grafik Wear Volume terhadap Kecepatan dengan Pembebanan Konstan 120 N

Dari grafik diatas terlihat bahwa nilai volume yang aus mengikuti nilai wear rate yang didapatkan oleh gesekan logam dan unsur paduan dengan penguat logam juga. Tren grafik selalu turun dengan semakin bertambahnya kecepatan yang diberikan. Pada kecepatan $0,19201 \mathrm{~m} / \mathrm{s}$ volume aus yang terjadi sebesar $3,791036 \mathrm{~mm}^{3}, 0,20525 \mathrm{~m} / \mathrm{s}$ volume aus yang terjadi sebesar $0,702494 \mathrm{~mm}^{3}$ dan $0,21697 \mathrm{~m} / \mathrm{s}$ volume aus yang terjadi sebesar $0,168657 \mathrm{~mm}^{3}$. Hal ini dikarenakan material resin serbuk baja $15 \mathrm{~mm} \times 13 \mathrm{~mm} \times 7 \mathrm{~mm}$ yang diuji dengan kecepatan rendah pada keadaan volume teraus pertama mengakibatkan osilasi pembebanan, timbul fracture mekanik akibat rendahnya kecepatan putaran dan lamanya pengujian serta memperlambat pergesekan berdasarkan jarak konstan sehingga terjadi fatigue sedangkan pada kecepatan yang lebih tinggi akan lebih cepat mengalami peningkatan temperatur pada permukaan kontaknya, 
mempercepat gesekan yang terjadi pada pin dan memperkeras permukaan pada material alternatif tersebut sehingga gerusan pada pin akan makin lambat serta material menjadi lebih sulit terkikis dan volume material semakin berkurang dikarenakan oleh permukaan disk juga yang semakin halus dan terdapat konsentrasi serbuk baja dipermukaan disk. serta setelah dilakukan pengujian dapat dilihat pada Gambar 5, 6 dan 7 dibawah ini.

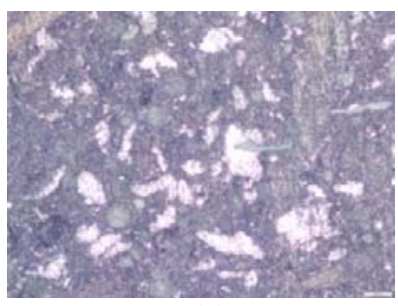

(a)

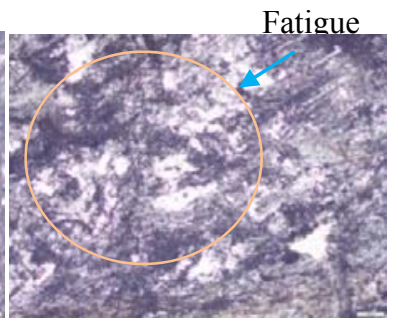

(b)
Gambar 5 (a). Foto Mikro 100x Permukaan Material Resin Serbuk Baja $15 \mathrm{~mm} \times 13 \mathrm{~mm} \times 7 \mathrm{~mm}$ I sebelum Pengujian. (b).Foto mikro 100x Permukaan Material Resin Serbuk Baja $15 \mathrm{~mm} \times 13 \mathrm{~mm} \times 7$ mm I setelah Pengujian

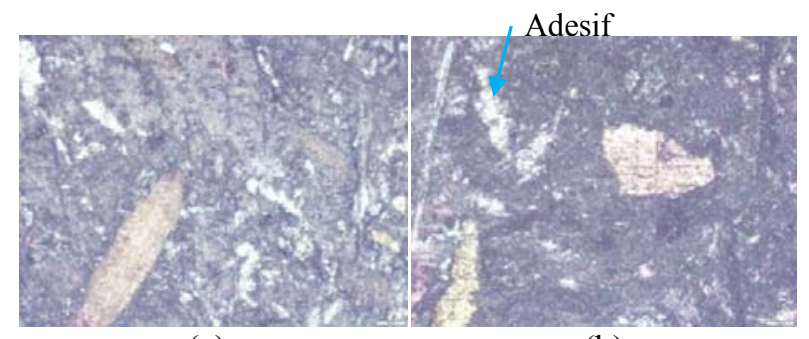

(a)

(b)

Gambar 6 (a). Foto Mikro 100x Permukaan Material Resin Serbuk Baja $15 \mathrm{~mm} \times 13 \mathrm{~mm} \times 7 \mathrm{~mm}$ II sebelum Pengujian. (b). Foto Mikro 100x Permukaan Material Resin Serbuk Baja $15 \mathrm{~mm} \times 13$ $\mathrm{mm} \times 7 \mathrm{~mm}$ II setelah Pengujian

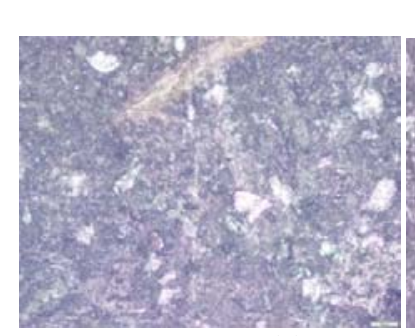

(a)

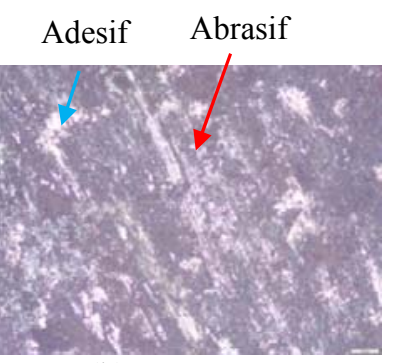

(b)
Gambar 7 (a). Foto Mikro 100x Permukaan Material Resin Serbuk Baja $15 \mathrm{~mm} \times 13 \mathrm{~mm} \times 7 \mathrm{~mm}$ III sebelum Pengujian. (b). Foto Mikro 100x Permukaan Material Resin Serbuk Baja $15 \mathrm{~mm} \times 13$ $\mathrm{mm} \times 7 \mathrm{~mm}$ III setelah Pengujian

Pada foto mikro diatas terlihat ada perbedaan kontur permukaan pada saat sebelum dilakukan pengujian dan setelah dilakukan pengujian. Struktur mikro material setelah pengujian terlihat lebih bergelombang dengan menunjukkan alur garis keausan arah diagonal daripada struktur material sebelum pengujian. Dapat terlihat pada gambar 5, 6 dan 7 (b) terdapat guratan guratan akibat goresan yang mengindikasikan bahwa material terkikis atau terabrasi serta teradesi dan tren cenderung menurun secara drastis yang disebabkan oleh adanya osilasi saat pembebanan dan interaksi permukaan yang mengalami beban berulang akan mengarah pada pembentukan retak-retak mikro. Retak-retak mikro tersebut pada akhirnya menyatu dan menghasilkan pengelupasan material. Hal ini akan berakibat pada meningkatnya tegangan gesek.. Hal ini disebabkan karena perbedaan nilai kekerasan antara dua material uji yang saling kontak.

Material resin serbuk baja $15 \mathrm{~mm} \times 13 \mathrm{~mm} \times 7 \mathrm{~mm}$ cenderung lebih lunak dari pada stainless steel AISI 316. Penelitian ini dilakukan secara eksperimental penelitian secara langsung. Ketika penelitian dilakukan dengan pemberian beban, penekanan dari beban tersebut tidak sempurna. Penekanan dari beban seharusnya terjadi secara konstan sehingga tidak menimbulkan fatigue, namun pada kenyataannya penekanan beban yang terjadi mengalami osilasi yang begitu besar pada percobaan pertama. Pada material uji kedua dan ketiga terlihat gerusan berupa garis putih diagonal kekiri dimana pada spesimen kedua dan ketiga ini osilasi yang terjadi tidak begitu besar sehingga material mengalami scratching sekaligus pengelupasan yang lebih sedikit seiring meningkatnya kecepatan.

\section{Analisa Pengaruh Kecepatan terhadap Wear Rate dengan Tiga Variasi Pembebanan}

Hasil dari pengujian penelitian laju keausan berikutnya dilakukan tiga variasi beban pengujian yaitu pada kecepatan $80 \mathrm{~N}, 100 \mathrm{~N}$ dan $120 \mathrm{~N}$. Grafik hubungan beban dengan wear rate resin serbuk baja $15 \mathrm{~mm} \times 14 \mathrm{~mm} \times 9 \mathrm{~mm}$ dapat dilihat pada gambar 8 dibawah ini.

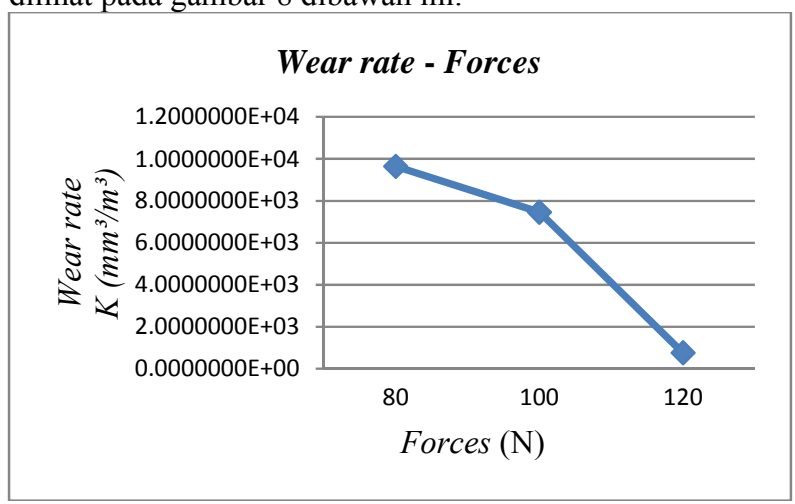

Gambar 8 . Grafik Wear Rate terhadap Beban dengan Kecepatan Konstan Maksimum 59,2 rpm

Nilai wear rate terlihat berbanding lurus dengan pembebanan, semakin besar beban yang diberikan, semakin turun pula laju keausan material. Perubahan grafik wear rate terlihat tidak linear. Dimulai dari beban $80 \mathrm{~N}$ hingga beban $120 \mathrm{~N}$ tren grafik selalu turun. Pada kecepatan beban $80 \mathrm{~N}$ nilai wear rate-nya adalah $9,6405766 \times 10^{3} \mathrm{~mm}^{3} / \mathrm{m}^{3}$, pada beban $100 \mathrm{~N}$ nilai wear rate-nya berkurang lagi sebesar $7,4628473 \times 10^{3} \mathrm{~mm}^{3} / \mathrm{m} 3$ dan semakin rendah pada beban $120 \mathrm{~N} \mathrm{~m} / \mathrm{s}$ yaitu $7,5783130 \times 10^{2} \mathrm{~mm}^{3} / \mathrm{m}^{3}$.

Secara teoritis, nilai wear rate akan semakin besar dengan semakin besarnya nilai beban yang diberikan, namun tidak pada material alternatif ini kecenderungan saat beban pertama hingga kedua terjadi penurunan laju keausan relatif kecil dan secara signifikan terjadi penurunan yang lebih besar dibandingkan dengan pembebanan kedua dan ketiga. Hal ini dikarenakan material resin serbuk baja yang diuji dengan beban yang lebih tinggi akan lebih cepat mengalami deformasi plastis, sentuhan pada konsentrasi komposisi logam antar logam, peningkatan temperatur yang semakin memperkeras permukaannya, kontak asperity yang sama sehingga gerusan yang terjadi relatif lebih kecil, pengaruh dari masing-masing spesimen yang mempunyai harga kekerasan yang relatif berbeda, setiap permukaan spesimen pada permukaan komposisi material yang dominan terhadap 
material logam antar permukaan tergesek dan konsentrasi dari bubuk resin pada permukaan disk yang relatif keras juga mempengaruhi penurunan laju keausan. Perbedaan laju keausan pada spesimen kedua dan ketiga diakibatkan oleh adanya fatigue selain dari pengujian pertama saat pembebanan minimum. Pada variasi kecepatan dengan pembebanan maksimum material resin serbuk baja $15 \mathrm{~mm} \times$ $14 \mathrm{~mm} \times 9 \mathrm{~mm}$ terjadi mekanisme abrasif dan adesif. Kontak material logam dengan material yang ada unsur logam didalamnya dengan paduan tertentu jika temperatur meningkat maka akan memperkeras kondisi permukaan material ditambah dengan waktu pengujian yang lebih cepat karena lintasan dianggap konstan sepanjang 1200 meter dan permukaan disk stainless steel 316 yang halus sehingga konsentrasi serbuk baja yang tergores mendominasi kontak disk stainless steel dan kontak gesekan material alternatif resin serbuk baja $15 \mathrm{~mm} \times 14 \mathrm{~mm} \times 9 \mathrm{~mm}$.

D. Analisa Pengaruh Kecepatan terhadap Wear Volume dengan Tiga Variasi Pembebanan.

Selain nilai wear rate, didaptkan nilai volume aus pada material dengan variasi kecepatan dimana terjadi penurunan volume aus semakin meningkatnya pembebanan. Peningkatan ini terjadi karena temepratur dan gesekan antar permukaan logam akibat kecepatan tinggi. Dapat dilihat pada gambar 9 dibawah ini.

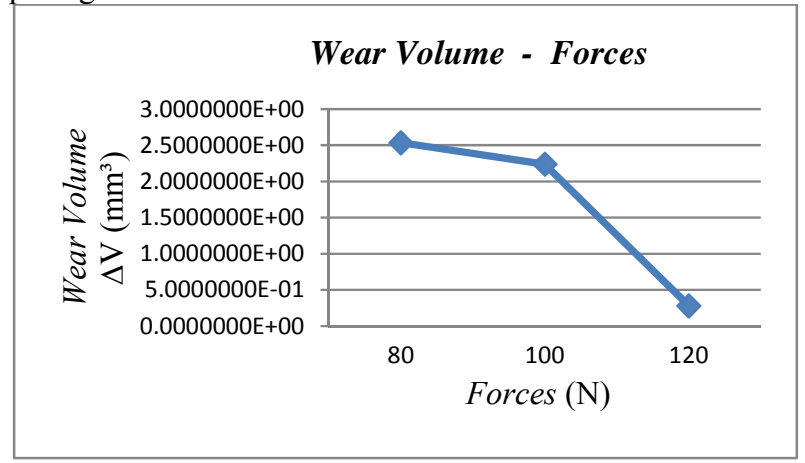

Gambar 9. Grafik Wear Volume terhadap Variasi Beban dengan Kecepatan Konstan 59,2 rpm

Dari grafik diatas terlihat bahwa nilai volume yang aus mengikuti nilai wear rate yang didapatkan oleh gesekan logam dan unsur paduan logam juga. Tren grafik selalu turun dengan semakin bertambahnya beban yang diberikan. Hal ini dikarenakan material resin serbuk baja $15 \mathrm{~mm} \times 13$ $\mathrm{mm} \times 9 \mathrm{~mm}$ yang diuji dengan konstan maksimum akan lebih cepat mengalami peningkatan temperatur pada permukaan kontaknya, mempercepat gesekan yang terjadi pada pin dan memperkeras permukaan pada material alternatif tersebut sehingga gerusan pada pin akan makin lambat serta material menjadi lebih sulit terkikis dan volume material semakin berkurang dikarenakan oleh permukaan disk juga yang semakin halus dan terdapat konsentrasi serbuk baja dipermukaan disk. Pada percobaan ketiga terjadi osilasi dan penggerusan material alternatif akibat pembebanan, sehingga tren mengalami penurunan yang relatif lebih besar dibandingkan pengujian sebelumnya serta Berikut adalah foto struktur permukaan material alternatif resin serbuk baja sebelum dan setelah pengujian, dapat dilihat pada gambar 10,11 dan 12 dibawah ini.

Pada foto mikro diatas terlihat ada perbedaan kontur permukaan pada saat sebelum dilakukan pengujian dan setelah dilakukan pengujian. Struktur mikro material setelah pengujian terlihat lebih bergelombang dengan menunjukkan alur garis keausan arah diagonal daripada struktur material sebelum pengujian. Dapat terlihat pada gambar 10, 11 dan 12 (b) terdapat guratan-guratan akibat goresan yang mengindikasikan bahwa material terkikis atau terabrasi serta teradesi. penekanan dari beban tersebut tidak sempurna. Penekanan dari beban seharusnya terjadi secara konstan, namun pada kenyataannya penekanan beban yang terjadi mengalami oskilasi, sehingga material mengalami scratching sekaligus pengelupasan yang begitu besar diantara pembebanan $80 \mathrm{~N}$ dan $100 \mathrm{~N}$.

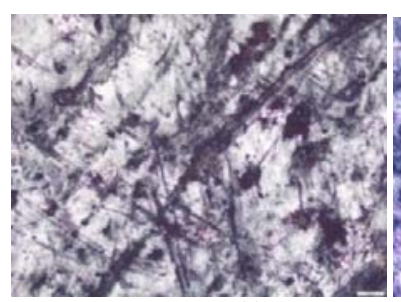

(a)

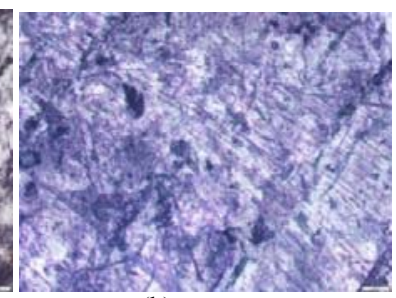

(b)
Gambar 10 (a). Foto Mikro 100x Permukaan Material Resin Serbuk Baja $15 \mathrm{~mm} \times 14 \mathrm{~mm} \times 9 \mathrm{~mm}$ I sebelum Pengujian.(b) Foto Mikro 100x Permukaan Material Resin Serbuk Baja $15 \mathrm{~mm} \times$ $14 \mathrm{~mm} \times 9 \mathrm{~mm}$ I setelah Pengujian

Abrasif Adesif

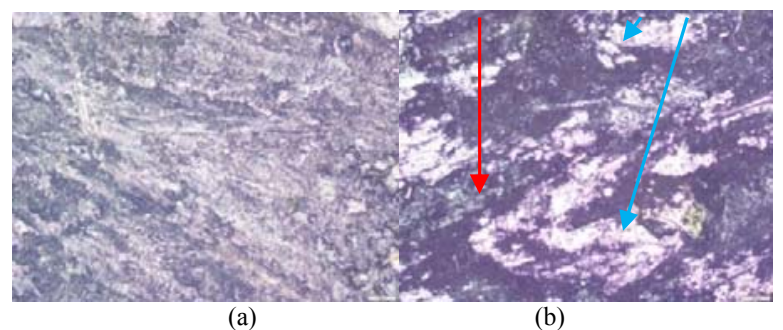

Gambar 11 (a). Foto Mikro 100x Permukaan Material Resin Serbuk Baja $15 \mathrm{~mm} \times 14 \mathrm{~mm} \times 9 \mathrm{~mm}$ II sebelum Pengujian. (b). Foto Mikro 100x Permukaan Material Resin Serbuk Baja $15 \mathrm{~mm} \times$ $14 \mathrm{~mm} \times 9 \mathrm{~mm}$ II setelah Pengujian

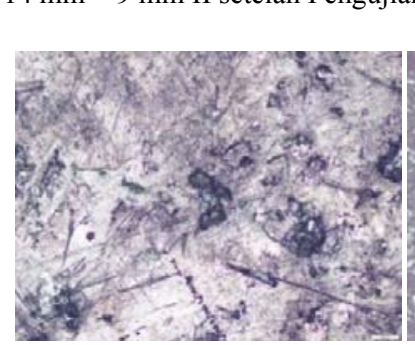

(a)

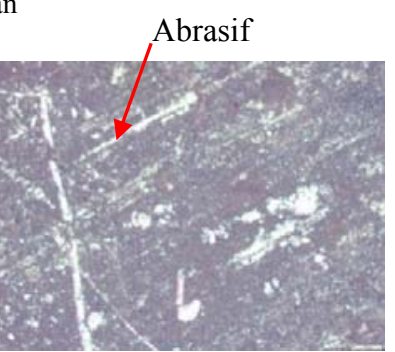

(b)
Gambar 12 (a). Foto Mikro 100x Permukaan Material Resin Serbuk Baja $15 \mathrm{~mm} \times 14 \mathrm{~mm} \times 9 \mathrm{~mm}$ III sebelum Pengujian. (b). Foto Mikro 100x Permukaan Material Resin Serbuk Baja $15 \mathrm{~mm} \times$ $14 \mathrm{~mm} \times 9 \mathrm{~mm}$ III setelah Pengujian

Pada foto mikro diatas terlihat ada perbedaan kontur permukaan pada saat sebelum dilakukan pengujian dan setelah dilakukan pengujian. Struktur mikro material setelah pengujian terlihat lebih bergelombang dengan menunjukkan alur garis keausan arah diagonal daripada struktur material sebelum pengujian. Dapat terlihat pada gambar 10 dan 11 (b) terdapat guratan guratan yang besar (abrasi) akibat goresan partikel keras (asperity) dari material tertentu meluncur pada permukaan resin serbuk baja yang lebih lunak sehingga terjadi penetrasi atau pemotongan material yang mengindikasikan bahwa material terkikis atau terabrasi dan teradesi dalam skala besar. Pada percobaan pertama dan 
kedua terjadi fatigue dan fracture mechanic dan kemudian terjadi abrasi. Penekanan dari beban seharusnya terjadi secara konstan, namun pada kenyataannya penekanan beban yang terjadi mengalami osilasi yang begitu besar pada percobaan pertama berikut harga kekerasan yang lebih kecil spesimen pertama.

\section{E. Grafik Perbandingan Wear Rate dan Volume Aus} terhadap Variasi Kecepatan dan Beban

Dari data yang diperoleh, dapat dianalisa perbandingan nilai wear rate dan volume batas aus yang menunjukkan besarnya volume aus atau bagian yang terkikis setiap satu satuan kecepatan dan gaya antara material resin serbuk baja $15 \mathrm{~mm} \times 13 \mathrm{~mm} \times 7 \mathrm{~mm}$ dan resin serbuk baja $15 \mathrm{~mm} \times 14$ $\mathrm{mm} \times 9 \mathrm{~mm}$ pada jarak tempuh konstan $1200 \mathrm{~m}$. Besar kecepatan suatu material yang bergerak, beban yang menekan dan mengalami kontak mempengaruhi laju keausan (wear rate) dan volume aus (wear volume). Variasi pengujian dapat dilihat pada gambar 13 dan 14 dibawah ini.

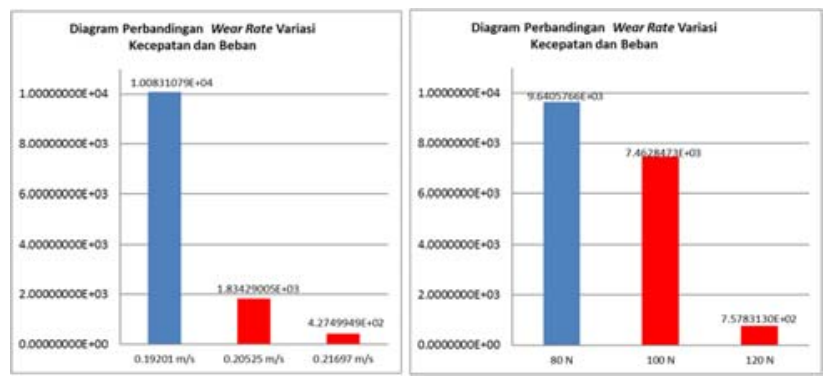

Gambar 13 Diagram Batang Perbandingan Nilai Wear Rate terhadap Kecepatan dan Beban antara Material Resin Serbuk Baja $15 \mathrm{~mm} \times 13 \mathrm{~mm} \times 7 \mathrm{~mm}$ dan Resin Serbuk Baja15 mm $\times 14 \mathrm{~mm} \times$ $9 \mathrm{~mm}$.

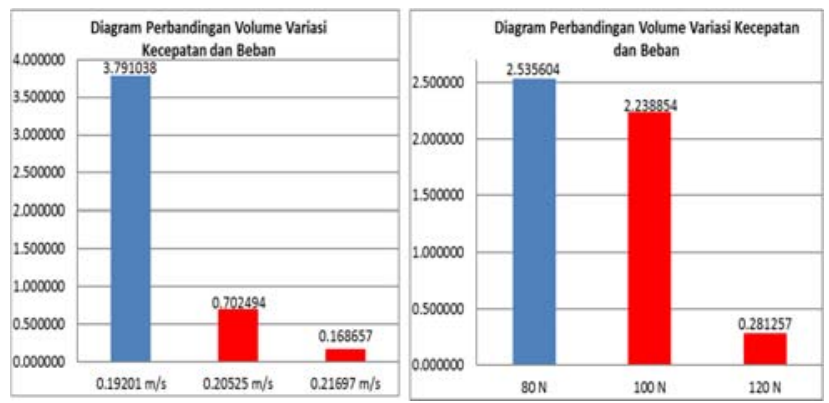

Gambar 14 Diagram Batang Perbandingan Nilai Wear Volume terhadap Kecepatan dan Beban antara Material Resin Serbuk Baja $15 \mathrm{~mm} \times 13 \mathrm{~mm} \times 7 \mathrm{~mm}$ dan Resin Serbuk Baja $15 \mathrm{~mm} \times 14 \mathrm{~mm}$ $\times 9 \mathrm{~mm}$.

Dari grafik diatas terlihat bahwa perbandingan wear rate dan wear volume ditampilkan dalam urutan terbesar hingga terkecil dari kombinasi dua variasi pengujian. material resin serbuk baja $15 \mathrm{~mm} \times 13 \mathrm{~mm} \times 7 \mathrm{~mm}$ dengan beban konstan maksimum pada kecepatan maksimum sebesar $0,21697 \mathrm{~m} / \mathrm{s}$ adalah paling rendah dibandingkan nilai wear rate dari variasi kecepatan konstan maksimum pada beban maksimum material resin serbuk baja $15 \mathrm{~mm} \times 14 \mathrm{~mm} \times 9$ $\mathrm{mm}$. Hal ini berarti bahwa variasi beban konstan maksimum dan beban maksimum material resin serbuk baja $15 \mathrm{~mm} \times$ $13 \mathrm{~mm} \times 7 \mathrm{~mm}$ lebih baik dan lebih tahan terhadap aus dibandingkan variasi kecepatan konstan maksimum dan beban maksimum pada spesimen uji material resin serbuk baja $15 \mathrm{~mm} \times 14 \mathrm{~mm} \times 9 \mathrm{~mm}$.
Material resin serbuk baja $15 \mathrm{~mm} \times 14 \mathrm{~mm} \times 9 \mathrm{~mm}$ pada variasi kecepatan konstan maksimum terhadap beban minimum $80 \mathrm{~N}$ adalah paling tinggi dibandingkan dengan nilai wear rate material resin serbuk baja $15 \mathrm{~mm} \times 13 \mathrm{~mm} \times$ $7 \mathrm{~mm}$ pada variasi kecepatan maksimum dengan beban minimum dan terlihat bahwa prilaku dari hasil pengujian mengalami perbedaan laju keausan dengan variasi yang sama antara material resin serbuk baja $15 \mathrm{~mm} \times 13 \mathrm{~mm} \times 7$ $\mathrm{mm}$ dan resin serbuk baja $15 \mathrm{~mm} \times 14 \mathrm{~mm} \times 9 \mathrm{~mm}$ pada parameter pengujian beban konstan maksimum dan kecepatan maksimum dengan nilai laju keausan sebesar $757,8313 \mathrm{~mm}^{3} / \mathrm{m}^{3}$ pada material resin serbuk baja $15 \mathrm{~mm} \times$ $13 \mathrm{~mm} \times 7 \mathrm{~mm}$ dan $427,4994 \mathrm{~mm}^{3} / \mathrm{m}^{3}$ material resin serbuk baja $15 \mathrm{~mm} \times 14 \mathrm{~mm} \times 9 \mathrm{~mm}$ diiringi dengan nilai wear volume sebesar $0,281257 \mathrm{~mm}^{3}$ dan $0,168657 \mathrm{~mm}^{3}$ adalah nilai laju keausan dan volume aus yang paling kecil.

Hal ini juga berarti bahwa material resin serbuk baja 15 $\mathrm{mm} \times 13 \mathrm{~mm} \times 7 \mathrm{~mm}$ dan material resin serbuk baja $15 \mathrm{~mm}$ $\times 14 \mathrm{~mm} \times 9 \mathrm{~mm}$ pada variasi kecepatan minimum saat pembebanan konstan maksimum dan kecepatan maksimum konstan pada pembebanan $80 \mathrm{~N}$ memiliki ketahanan yang paling buruk diantara keseluruhan variasi kecepatan dan pembebanan dengan nilai wear rate dan wear volume $10083,1079 \mathrm{~mm}^{3} / \mathrm{m}^{3}$ dan $9640,5766 \mathrm{~mm}^{3} / \mathrm{m}^{3}$. Saat kecepatan $56 \mathrm{rpm}$ dengan pembebanan maksimum material resin serbuk baja $15 \mathrm{~mm} \times 13 \mathrm{~mm} \times 7 \mathrm{~mm} \mathrm{4,07}$ lebih baik daripada material resin serbuk baja $15 \mathrm{~mm} \times 14 \mathrm{~mm} \times 9 \mathrm{~mm}$ saat pembebanan $100 \mathrm{~N}$ dengan kecepatan konstan maksimum dan Saat pembebanan $120 \mathrm{~N}$ dengan kecepatan konstan maksimum material resin serbuk baja $15 \mathrm{~mm} \times 14$ $\mathrm{mm} \times 9 \mathrm{~mm} 1,77$ lebih baik dibandingkan dengan material resin serbuk baja $15 \mathrm{~mm} \times 14 \mathrm{~mm} \times 7 \mathrm{~mm}$ saat pembebanan konstan maksimum $120 \mathrm{~N}$ dengan kecepatan maksimum, yaitu nilai wear rate $56 \mathrm{rpm}$ pada beban konstan maksimum $120 \mathrm{~N}$ sebesar $427,499485 \mathrm{~mm}^{3} / \mathrm{m}^{3}$ dan 757,831295 $\mathrm{mm}^{3} / \mathrm{m}^{3}$.

Secara teoritis, nilai wear rate akan semakin tinggi dengan semakin besarnya nilai kecepatan dan beban yang diberikan. Hal ini berbeda pada material uji resin serbuk baja $15 \mathrm{~mm}$ $\times 13 \mathrm{~mm} \times 7 \mathrm{~mm}$ dan resin serbuk baja $15 \mathrm{~mm} \times 14 \mathrm{~mm} \times 9$ $\mathrm{mm}$ dengan indikasi keausan yang telah terjadi dan dikarenakan material yang diuji dengan kecepatan yang lebih tinggi akan lebih cepat mengalami peningkatan temperatur pada permukaan kontaknya, mempercepat gesekan yang terjadi pada pin sehingga gerusan pada pin akan semakin lambat karena pengaruh konsentrasi serbuk halus, kehalusan permukaan disk setelah dilakukan pengujian sebelumnya serta material menjadi lebih sulit terkikis. pengaruh deformasi plastis, fracture adalah hal yang dominan terjadi setelah terjadi selisih nilai laju keausan yang besar.

Berdasarkan nilai laju keausan dan wear volume tersebut diatas bahwa nilai variasi kecepatan dan beban merupakan keterbatasan dari alat uji tribometer tipe pin on disk. Proses perlakuan pengujian dilakukan dengan kondisi spesifikasi maksimum pada alat uji tribometer tipe pin on disk dengan kecepatan sebesar $0,21697 \mathrm{~m} / \mathrm{s}$ dan beban $120 \mathrm{~N}$. Skala perbandingan kondisi real yang melibatkan pengaruh kecepatan dan beban berbanding 1:65,87 untuk skala kecepatan dan 1:59,66 untuk skala pembebanan.

\section{F. Perhitungan Umur Hidup (lifetime) Material Uji}

Pada eksperimen ini setelah dicari nilai laju keausan (wear rate), maka akan didapatkan umur hidup dari dua 
spesimen uji dengan variasi pengujian yang berbeda. perhitungan umur hidup masing-masing material alternatif resin serbuk baja menggunakan rumus sebagai berikut:

$$
t=\frac{L}{v}
$$

$\mathrm{t}=$ umur hidup material (tahun)

$\mathrm{L}=$ panjang lintasan (meter)

$\mathrm{v}=$ kecepatan rata - rata $(\mathrm{m} / \mathrm{s})$

Dimana untuk mencari nilai L dapat diperoleh dengan menggunakan rumus:

$$
\mathrm{L}=\frac{\mathrm{VxH}}{\mathrm{kxW}}
$$

$$
\begin{aligned}
& \mathrm{L}=\text { Panjang Lintasan }(\text { meter }) \\
& \mathrm{V}=\text { Volume BatasAus }\left(\mathrm{m}^{3}\right) \\
& \mathrm{H}=\text { Nilai Kekerasan Material } \\
& \mathrm{K}=\text { Nilai Laju Keausan }\left(\mathrm{m}^{2} / \mathrm{N}\right) \\
& \mathrm{W}=\text { Berat Pembebanan }(\mathrm{N})
\end{aligned}
$$

Nilai Life time untuk tiga prilaku pengujian berdasarkan

\begin{tabular}{|c|c|c|c|c|c|c|c|c|c|}
\hline $\begin{array}{c}\text { Speed Control } \\
(\mathrm{mm})\end{array}$ & $\begin{array}{c}\text { Sididing Spped } \\
V(\mathrm{~ms})\end{array}$ & $\begin{array}{c}H \\
\left(\mathrm{Nm}^{2}\right)^{2}\end{array}$ & $\begin{array}{l}\text { Sididing Distance L } \\
\text { (II) }\end{array}$ & VSR (min) & $F(N)$ & $\left.\mathrm{K}\left(\mathrm{m}^{3} \mathrm{~m}^{\mathrm{m}}\right)^{3}\right)$ & I(Secons) & $t(\mathrm{dam})$ & t(Tahin) \\
\hline 52.4 & 0.19201 & $3.856+18$ & 6887940.53 & 21438 & 120 & $1.0083109 \mathrm{EST}+\mathrm{A}$ & 3534557,929945 & 98616.6216477 & 1.120642 \\
\hline 59.2 & 0.21697 & $3.656+18$ & 10245513 & 21438 & $\infty$ & $9.6405656560+13$ & 40559979.8152424 & 122888838382 & 1.482799 \\
\hline 59.2 & 0.21697 & 4.0EE+18 & 1149053 & 21438 & 100 & $7.46280435 E+13$ & 5255773380202564 & 14710.498883 & 1.699881 \\
\hline
\end{tabular}
variasi kecepatan dan beban dengan nilai konstan pengujian berupa kecepatan: $0,21697 \mathrm{~m} / \mathrm{s}$ untuk beban $80 \mathrm{~N}$ dan 100 $\mathrm{N}$, kecepatan $0,19201 \mathrm{~m} / \mathrm{s}$ untuk beban $120 \mathrm{~N}$. Berdasarkan perolehan laju keausan dan volume aus maka didapatkan hasil perhitungan yang ditampilkan pada tabel 4.3 dibawah ini.

\section{KESIMPULAN}

1. Nilai wear rate antara material aternatif resin serbuk baja yang memiliki dimensi sebesar $15 \mathrm{~mm} \times 13 \mathrm{~mm} \times 7 \mathrm{~mm}$ dengan Stainless Steel AISI 316 yang mengalami kontak akibat tiga variasi kecepatan 52,4 rpm, $56 \mathrm{rpm}$ dan 59,2 rpm terhadap pembebanan konstan maksimum $120 \mathrm{~N}$ akan semakin mengalami penurunan, yaitu nilai rata rata sebesar $4,1149658 \times 10^{3} \mathrm{~mm}^{3} / \mathrm{m}^{3}$.

2. Nilai wear rate antara material aternatif resin serbuk baja yang memiliki dimensi sebesar $15 \mathrm{~mm} \times 14 \mathrm{~mm} \times 9 \mathrm{~mm}$ dengan Stainless Steel AISI 316 yang mengalami kontak akibat tiga variasi beban $80 \mathrm{~N}, 100 \mathrm{~N}$ dan $120 \mathrm{~N}$ mengalami penurunan, yaitu nilai rata - rata sebesar $5,9537517 \times 10^{3} \mathrm{~mm}^{3} / \mathrm{m}^{3}$.

3. Mekanisme Keausan yang terjadi pada material $15 \mathrm{~mm} \times$ $13 \mathrm{~mm} \times 7 \mathrm{~mm}$ dan $15 \mathrm{~mm} \times 14 \mathrm{~mm} \times 9 \mathrm{~mm}$ didominasi oleh mekanisme keausan fatigue dengan selisih dari nilai keausan yang signifikan besar pada saat percobaan pertama, abrasif dan guratan dan pelebaran kontur permukaan dapat dilihat pada foto mikro 100x pada permukaan material dengan mengindikasikan terjadinya abrasif dan adesif.

4. Umur Hidup (lifetime) material resin serbuk baja berdasarkan hasil prilaku pengujian variasi kecepatan dan pembebanan. Untuk material $15 \mathrm{~mm} \times 13 \mathrm{~mm} \times 7$ $\mathrm{mm}$ selisih umur prilaku terkecil terdapat pada variasi kecepatan dan pembebanan konstan dengan perolehan umur selama jangka waktu 1,120642 tahun saat kondisi prilaku pengujian beban $120 \mathrm{~N}$ dan kecepatan 0,19201 $\mathrm{m} / \mathrm{s}$.

5. Umur Hidup (lifetime) material resin serbuk baja berdasarkan hasil prilaku pengujian variasi kecepatan dan pembebanan. Untuk material $15 \mathrm{~mm} \times 13 \mathrm{~mm} \times 9$ $\mathrm{mm}$ selisih umur prilaku terkecil terdapat pada variasi pembebanan dan kecepatan konstan dengan perolehan umur selama jangka waktu 1,482749 dan 1,679281 tahun saat kondisi prilaku pengujian beban $80 \mathrm{~N}$ dan $100 \mathrm{~N}$ dan dengan kecepatan 0,21697 m/s.

\section{DAFTAR PUSTAKA}

[1] Akkus, A. 2014. "Research on Wear Rate and Mechanical Properties of Brake Sabots (Shoes) Used in Rail Rolling Stocks". Turkey: Chumriyet University.

[2] Marusic, V., Vitez, L,. Kladaric I, 2004. "Tribological Of Brake Shoes with Increased Phosphorus Content Properties". METABK 43 (4) 323-327, ISSN:0543-5846.

[3] Stachowiak, G.,W And A.,W, Batchelor. 2000. "Engineering Tribology", Elsevier Butterworth. Amerika Serikat.

[4] Tarina, W. D., September. 2012. "Studi Eksperimental Laju Keausan (Specific Wear Rate) Resin Akrilik dengan Penambahan Serat Penguat pada Dental Prosthesis". Teknik Mesin ITS Vol 1, ISSN:2301-9271. 